\title{
Communication
}

\section{Impact of COVID-19 Pandemic on Total Mortality in Poland}

\author{
Kamil Barański *(D), Grzegorz Brożek (), Małgorzata Kowalska (1), Angelina Kaleta-Pilarska (i) \\ and Jan Eugeniusz Zejda
}

Citation: Barański, K.; Brożek, G.; Kowalska, M.; Kaleta-Pilarska, A.; Zejda, J.E. Impact of COVID-19 Pandemic on Total Mortality in Poland. Int. J. Environ. Res. Public Health 2021, 18, 4388. https://doi.org/ 10.3390/ijerph18084388

Academic Editor: Giuseppe Biondi Zoccai

Received: 26 February 2021

Accepted: 15 April 2021

Published: 20 April 2021

Publisher's Note: MDPI stays neutral with regard to jurisdictional claims in published maps and institutional affiliations.

Copyright: (c) 2021 by the authors. Licensee MDPI, Basel, Switzerland. This article is an open access article distributed under the terms and conditions of the Creative Commons Attribution (CC BY) license (https:/ / creativecommons.org/licenses/by/ $4.0 /)$.
Department of Epidemiology, Poland Faculty of Medical Sciences in Katowice, Medical University of Silesia in Katowice, 40-752 Katowice, Poland; gbrozek@sum.edu.pl (G.B.); mkowalska@sum.edu.pl (M.K.); akaleta@sum.edu.pl (A.K.-P.); jzejda@sum.edu.pl (J.E.Z.)

* Correspondence: kbaranski@sum.edu.pl; Tel.: +48-208-85-38

\begin{abstract}
Background: According to published data the number of deaths attributed to COVID-19 is underestimated between 30 and $80 \%$. Aim: The aim of this study is to assess the impact of COVID-19 on total mortality of Poland and the Silesian voivodship. Methods: Secondary epidemiological data on COVID-19 deaths were obtained from the Ministry of Health registry and data on total mortality were gathered from the National Statistical Office and Registry Office in Poland. Three scenarios were used to estimated COVID-19 deaths: real number + an extra 30\%, 60\%, and 70\% excess total deaths. Results: In 2020, there were 73,254, 64,584, and 67,677 excess deaths in comparison to 2017-2019, respectively. For the Silesian voivodship, it was 8339, 7946, and 8701, respectively. The total mean increase in deaths was $16 \%$ for the whole country and the Silesian voivodship. The simulation for 30\% extra COVID-19 deaths gave COVID-19 mortality equal to $12.5 \% ; n=50,708$ deaths, for extra $60 \% ; 17.9 \% n=72,866$ and for extra $70 \% ; 19.7 \% n=80,251$ for Poland; and $11.9 \%$ ( $n=6072), 17.2 \%(n=8740), 24.2 \%(n=12,297)$, respectively, for the Silesian voivodship. Conclusions: The participation of COVID-19 in total deaths should not exceed $20 \%$ for Poland and $24 \%$ for the Silesian voivodship in 2020.
\end{abstract}

Keywords: COVID-19; mortality; estimation; coronavirus; Poland; Silesia

\section{Introduction}

In Poland (pop. 37,672,367), the first confirmed case, as well as the first death of COVID-19, was reported in March 2020. Initially, the spread of infection was slow with the highest numbers of infections recorded in the Silesia voivodship (pop. 4,517,635, density 3663 people $/ \mathrm{km}^{2}$, a highly industrial region on South of Poland) [1].

The registered number of deaths in Poland attributed to COVID-19 in 2020 was 28,551. At the same time, data regarding new cases of infections of COVID-19 showed the number to be 1,267,051 (31 December 2020). The COVID-19 fatality case ratio was $2.2 \%$. Currently (26 February 2021), case fatality ratio is $2.5 \%$. In 2020, during the COVID-19 pandemic, the total number of deaths in Poland increased to 71,541 in comparison to 2019. Globally, in Poland in 2020,1.26\% people died; this was an increase of $0.18 \%$ compared to 2019 [2]. In Poland, the number of deaths as well as mortality rates in 2017, 2018, and 2019 were stable and did not differ significantly. There is no doubt that the pandemic increased the general and specific deaths globally, as well as observed in Poland and the Silesian voivodship [3]. Current published data regarding COVID-19 suggest an underestimation of the number of deaths attributed to COVID-19 in different World locations by at least 35\% [4]. Table 1 presents some estimates of COVID-19 attributed deaths. 
Table 1. Impact of COVID-19 on excess mortality in particular studies [4-8].

\begin{tabular}{|c|c|c|c|c|}
\hline Author/Paper & Excess Deaths & Country & Time & $\begin{array}{l}\text { Estimation Attributed to } \\
\text { COVID-19 }\end{array}$ \\
\hline $\begin{array}{l}\text { Woolf SH.: Excess Deaths from } \\
\text { COVID-19 and Other Causes, } \\
\text { March-July } 2020\end{array}$ & 225,530 & USA & March-July & $67 \%$ \\
\hline $\begin{array}{l}\text { Stokes AC.: Assessing the Impact of } \\
\text { the Covid-19 Pandemic on US } \\
\text { Mortality: A County-Level Analysis }\end{array}$ & 202,000 & USA & February-September & $\begin{array}{c}26.3 \% \\
\text { (95\% CI, } 20.1 \% \text { to } 32.5 \%)\end{array}$ \\
\hline \multirow{4}{*}{$\begin{array}{l}\text { Kung S.: Underestimation of Covid-19 } \\
\text { mortality during the pandemic }\end{array}$} & 210,959 & Europe 14 countries & January-September & $\begin{array}{c}62 \% \\
\text { (range: }-254.5 \% \\
\text { to } 197.1 \% \text { ) } \\
\end{array}$ \\
\hline & 505,657 & $\begin{array}{l}\text { Rest of the world } \\
8 \text { countries }\end{array}$ & January-September & $\begin{array}{c}52 \% \\
\text { (range: }-4.6 \text { to } 78.5 \% \text { ) }\end{array}$ \\
\hline & \multicolumn{4}{|c|}{ Total } \\
\hline & 716,616 & $\begin{array}{l}22 \text { countries all over } \\
\text { the world }\end{array}$ & January-September & $35-65 \%$ \\
\hline $\begin{array}{l}\text { Shiels.: Impact of Population Growth } \\
\text { and Aging on Estimates of Excess U.S. } \\
\text { Deaths during the } \\
\text { COVID-19 Pandemic }\end{array}$ & 218,000 & USA & March-August & $80 \%$ \\
\hline $\begin{array}{l}\text { Krelle H.: Understanding excess } \\
\text { mortality What is the fairest way to } \\
\text { compare COVID-19 } \\
\text { deaths internationally? }\end{array}$ & 38,499 & Wales and England & March-April & $71 \%$ \\
\hline
\end{tabular}

In addition, our population base study showed that the real number of COVID-19 infection in Silesia could be even four times higher than official statistics [9].

The lack of estimates regarding the potential underestimation of COVID-19 mortality in Poland, as well as the fact that the Silesian voivodship noticed one of the highest numbers of COVID-19 cases in Poland, were the reasons why we performed real number of COVID-19 death estimation based on analysis of available data.

\section{Materials and Methods}

The national reports regarding the number of COVID-19 deaths are available and updated daily on the Polish Ministry of Health's website. The reports contain information about the number of deaths by months, age, sex, and regional location (voivodships). Data about total mortality regardless of the cause of death are available from National Statistical Office reports and the national registry office. Data describing the monthly number of total deaths from 2017 to 2020 for Poland and the Silesian voivodship were used in the analysis. According to published results $[4,5,7,10]$ three scenarios for simulating the impact of COVID-19 on global mortality were used. The first scenario adds an extra $30 \%$ to the number of reported COVID-19 deaths (simulated COVID-19) from excess deaths, the second scenario adds an extra $60 \%$ (simulated COVID-19) from excess deaths to all reported COVID-19 deaths, and the third adds an extra $70 \%$ in total and by months (according to Ministry of Health reports). Our analysis and simulations covers the data collected between 4 March 2020 (first recorded COVID-19 case) and 31 December 2020 year. The reference point for estimating changes in year 2020 was a mean number of death from 3 years (2017, 2018, and 2019).

\section{Results}

\subsection{Number of Deaths in Poland and Silesian Voivodship}

In Poland, the total number of deaths (all causes of death) in 2017 was $n=405,404$; in $2018 n=414,074$; in $2019 n=410,981$; and in $2020 n=478,658$. The average number of deaths in 2017-2019 was $n=410,153$ and increased by $16.7 \%$ in 2020 (Table 2). The number of total deaths in the Silesian voivodship was stable between 2017 and 2019 (this number 
did not cross 53,000 in each of those years). In 2020, the yearly total mortality rapidly increased by $16 \%$, in comparison to the average number of deaths in a previous period (Table 3).

Table 2. Yearly and monthly number of total death registered between 2017 and 2020 in Poland.

\begin{tabular}{|c|c|c|c|c|c|c|c|c|c|c|c|c|c|}
\hline \multirow{2}{*}{ Year } & \multicolumn{13}{|c|}{ Number of Deaths in Poland } \\
\hline & Total & January & February & March & April & May & June & July & August & September & October & November & December \\
\hline 2017 & 405,404 & 43,778 & 37,352 & 34,902 & 32,032 & 31,972 & 30,155 & 30,848 & 30,997 & 30,929 & 34,426 & 32,463 & 35,550 \\
\hline 2018 & 414,074 & 37,822 & 37,080 & 41,787 & 34,639 & 32,452 & 30,752 & 32,741 & 31,877 & 31,330 & 34,274 & 32,961 & 36,359 \\
\hline 2019 & 410,981 & 39,020 & 36,382 & 36,117 & 33,614 & 33,229 & 33,079 & 32,822 & 31,971 & 31,721 & 34,178 & 32,809 & 36,039 \\
\hline 2020 & 478,658 & 36,560 & 35,250 & 36,863 & 34,116 & 33,703 & 32,637 & 33,537 & 34,773 & 34,181 & 49,343 & 64,474 & 53,493 \\
\hline$\% 2017$ & $18.1 \uparrow$ & $16.5 \downarrow$ & $5.6 \downarrow$ & $5.6 \uparrow$ & $6.5 \uparrow$ & $5.5 \uparrow$ & $8.2 \uparrow$ & $8.7 \uparrow$ & $12.1 \uparrow$ & $10.4 \uparrow$ & $43.3 \uparrow$ & $98.6 \uparrow$ & $50.5 \uparrow$ \\
\hline$\%{ }_{2018}$ & $15.6 \uparrow$ & $3.3 \downarrow$ & $5.0 \downarrow$ & $11.8 \downarrow$ & $1.5 \downarrow$ & $3.8 \uparrow$ & $6.1 \uparrow$ & $2.4 \uparrow$ & $9.1 \uparrow$ & $9.1 \uparrow$ & $43.9 \uparrow$ & $95.6 \uparrow$ & $47.1 \uparrow$ \\
\hline \%2019 & $16.4 \uparrow$ & $6.3 \downarrow$ & $3.1 \downarrow$ & $2.1 \uparrow$ & $1.5 \uparrow$ & $1.4 \uparrow$ & $1.3 \downarrow$ & $2.1 \uparrow$ & $8.7 \uparrow$ & $7.7 \uparrow$ & $44.3 \uparrow$ & $96.5 \uparrow$ & $48.4 \uparrow$ \\
\hline
\end{tabular}

Legend: in the last three lines, the \% represents the percentage change (decrease or increase) in the number of deaths in 2020 . Compared to previous years. $\uparrow:$ increase; $\downarrow$ : decrease.

Table 3. Yearly and monthly number of total death registered between 2017 and 2020 in Silesian voivodship.

\begin{tabular}{|c|c|c|c|c|c|c|c|c|c|c|c|c|c|}
\hline \multirow{2}{*}{ Year } & \multicolumn{13}{|c|}{ Total Deaths in Silesian Voivodship } \\
\hline & Total & January & February & March & April & May & June & July & August & September & October & November & December \\
\hline 2017 & 51,404 & 5773 & 4781 & 4429 & 4095 & 4014 & 3796 & 3891 & 3850 & 3931 & 4288 & 4181 & 4375 \\
\hline 2018 & 52,159 & 4669 & 4707 & 5270 & 4314 & 4020 & 3840 & 4187 & 3874 & 4051 & 4381 & 4184 & 4662 \\
\hline 2019 & 51,766 & 4990 & 4668 & 4470 & 4116 & 4204 & 4186 & 4177 & 4036 & 4006 & 4260 & 4135 & 4518 \\
\hline 2020 & 60,105 & 4689 & 4612 & 4735 & 4296 & 4355 & 4104 & 4245 & 4514 & 4299 & 6283 & 7746 & 6227 \\
\hline \%2017 & $17.0 \uparrow$ & $19.0 \downarrow$ & 3. $5 \downarrow$ & $7.0 \uparrow$ & $5.0 \uparrow$ & $8.5 \uparrow$ & $8.1 \uparrow$ & $9.0 \uparrow$ & $17.2 \uparrow$ & $9.4 \uparrow$ & $46.5 \uparrow$ & $85.2 \uparrow$ & $42.3 \uparrow$ \\
\hline$\% 2018$ & $15.2 \uparrow$ & $0.4 \downarrow$ & $2.0 \downarrow$ & $10.0 \downarrow$ & $0.4 \downarrow$ & $8.3 \uparrow$ & $7.0 \uparrow$ & $1.4 \uparrow$ & $16.5 \uparrow$ & $6.1 \uparrow$ & $43.4 \uparrow$ & $85.1 \uparrow$ & $33.6 \uparrow$ \\
\hline \%2019 & $16.1 \uparrow$ & $6.0 \uparrow$ & $1.2 \downarrow$ & $5.9 \uparrow$ & $4.4 \uparrow$ & $3.6 \uparrow$ & $2.0 \downarrow$ & $1.6 \uparrow$ & 11. $8 \uparrow$ & 7. $3 \uparrow$ & $47.3 \uparrow$ & $87.3 \uparrow$ & $37.8 \uparrow$ \\
\hline
\end{tabular}

Legend: in the last three lines, the \% represents the percentage change (decrease or increase) in the number of deaths in 2020 . Compared to previous years. $\uparrow:$ increase; $\downarrow$ : decrease.

\subsection{Simulated Number of Deaths}

From 2017 to 2019, the average number of death was 410,153, while in 2020 the number of all deaths was 478,658 . This shows a total of 68,505 excess deaths. In 2020 , there was a $16 \%$ increase in total mortality. Data representing the population of the entire voivodship and the country as a whole are useful for the estimation of undocumented mortality due to COVID-19. As a direct measure of the real number of COVID-19 death, it was not possible, indirect methods were applied to estimate the size of this problem. We based on the estimation methods used by other authors [10-15]. From 8 March 2020 to 31 December 2020 the number of deaths in Poland was 407,120 including 73,858 deaths reported as the excess number of death. In 2020, there were 28,551 deaths from COVID-19. At the same time, the frequency of COVID-19 deaths was 7\% from all deaths in 2020. Since the current literature suggest an underestimation of deaths attributed to COVID-19 death at least 35\% [4] we proposed three scenarios where we add extra $30 \%, 60 \%$, and $70 \%$ deaths from COVID-19 to officially reported deaths from COVID-19.

The results of our simulation showed that COVID-19 was a cause of $12.5 \%$ all deaths in 2020 (while considering 30\% extra deaths from excess deaths). In case of a simulation considering $60 \%$ of additional deaths, COVID-19 caused $17.9 \%$ of all deaths in 2020 . In the third scenario, we used the same quantification for the last simulation as reported by the Polish Ministry of Health, which was 70\% [11] and COVID-19 was a reason of $19.7 \%$ of all deaths in 2020 was $19.7 \%$ (Table 4). In a parallel simulation conducted for the Silesian voivodeship, while considering 30\%,60\%, and 70\% extra deaths from excess death, COVID-19 was a cause of $11.9 \%, 17.2 \%$, and $24.4 \%$ all deaths in 2020 respectively Table 5 . 
Table 4. Total and COVID-19 deaths in Poland in 2020.

\begin{tabular}{|c|c|c|c|c|c|c|c|c|c|c|c|c|c|c|c|}
\hline \multirow{3}{*}{ Month } & A1 & A2 & A3 & A4 & A5 & A6 & A7 & A8 & A9 & A10 & A11 & A12 & A13 & A14 & A15 \\
\hline & $\begin{array}{c}\text { An Average } \\
\text { Value in the } \\
\text { Period } \\
2017-2019\end{array}$ & $\begin{array}{c}\text { Deaths } \\
\text { in 2020 } \\
(n)\end{array}$ & $\begin{array}{c}\text { Reported } \\
\text { Deaths } \\
\text { COVID-19 }(n)\end{array}$ & $\begin{array}{l}\text { \% of COVID-19 } \\
\text { Deaths in Total } \\
\text { Deaths (2020) }\end{array}$ & $\begin{array}{l}\text { Excess } \\
\text { Deaths }\end{array}$ & $\begin{array}{l}\text { Proportion of } \\
\text { COVID-19 } \\
\text { Deaths in } \\
\text { Excess Deaths } \\
\quad(\%)\end{array}$ & $\begin{array}{l}\text { First Scenario } \\
\text { 30\% of Excess } \\
\text { Deaths }(n)\end{array}$ & $\begin{array}{c}\text { First Scenario } \\
\text { Reported }+ \\
\text { Estimated } \\
\text { COVID-19 } \\
\text { Deaths }(n)\end{array}$ & $\begin{array}{l}\text { First Scenario } \\
\text { Estimated } \\
\text { CoVID-19 Deaths } \\
\text { in Total Deaths } \\
\text { 30\%+Reported } \\
\text { Deaths (\%) }\end{array}$ & $\begin{array}{c}\text { Second } \\
\text { Scenario 60\% of } \\
\text { Excess Deaths } \\
\text { (n) }\end{array}$ & $\begin{array}{c}\text { Second } \\
\text { Scenario } \\
\text { Reported + } \\
\text { Estimated } \\
\text { COVID-19 } \\
\text { Deaths }(n)\end{array}$ & $\begin{array}{l}\text { Second Scenario } \\
\text { Estimated COVID-19 } \\
\text { Deaths in Total } \\
\text { Deaths 60\%+ } \\
\text { Reported Deaths (\%) }\end{array}$ & $\begin{array}{l}\text { Third Scenario } \\
70 \% \text { of Excess } \\
\text { Deaths }(n)\end{array}$ & $\begin{array}{c}\text { Third Scenario } \\
\text { Reported }+ \\
\text { Estimated } \\
\text { COVID-19 } \\
\text { Deaths }(n)\end{array}$ & $\begin{array}{l}\text { Third Scenario } \\
\text { Estimated COVID-19 } \\
\text { Deaths in Total } \\
\text { Deaths 70\%+ } \\
\text { Reported Deaths (\%) }\end{array}$ \\
\hline & A1 & A2 & A3 & $\mathrm{A} 3 / \mathrm{A} 2$ & $\mathbf{A} 2-\mathbf{A} 1$ & $\mathrm{~A} 3 / \mathrm{A} 5$ & $30 \% \times \mathbf{A} 5$ & $\mathrm{~A} 7+\mathrm{A} 3$ & $\mathrm{~A} 8 / \mathrm{A} 2$ & $60 \% \times \mathrm{A} 5$ & $\mathrm{~A} 10+\mathrm{A} 3$ & $\mathrm{~A} 11 / \mathrm{A} 2$ & $70 \% \times \mathrm{A} 5$ & $\mathrm{~A} 13+\mathrm{A} 3$ & $\mathrm{~A} 14 / \mathrm{A} 2$ \\
\hline March & 37,602 & 36,863 & 33 & 0.1 & -739 & $n / a$ & $n / a$ & $\mathrm{n} / \mathrm{a}$ & $n / a$ & $n / a$ & $n / a$ & $\mathrm{n} / \mathrm{a}$ & $n / a$ & $n / a$ & $\mathrm{n} / \mathrm{a}$ \\
\hline April & 33,428 & 34,116 & 610 & 1.8 & 688 & 88.7 & 206 & 816 & 2.4 & 412 & 1023 & 3.0 & 482 & 1091 & 3.2 \\
\hline May & 32,551 & 33,703 & 421 & 1.2 & 1152 & 36.5 & 345 & 767 & 2.3 & 691 & 1112 & 3.3 & 806 & 1227 & 3.6 \\
\hline June & 31,559 & 32,637 & 400 & 1.2 & 1078 & 37.1 & 323 & 723 & 2.2 & 646 & 1047 & 3.2 & 755 & 1154 & 3.5 \\
\hline July & 32,186 & 33,537 & 252 & 0.8 & 1351 & 18.7 & 405 & 657 & 2.0 & 810 & 1063 & 3.2 & 946 & 1197 & 3.6 \\
\hline September & 31,326 & 34,181 & 473 & 1.4 & 2855 & 16.6 & 856 & 1330 & 3.9 & 1713 & 2186 & 6.4 & 1999 & 2471 & 7.2 \\
\hline October & 34,292 & 49,343 & 3119 & 6.3 & $\begin{array}{l}15,051 \\
\end{array}$ & 20.7 & 4515 & 7634 & 15.5 & 9030 & 12,150 & 24.6 & 10,536 & 13,654 & 27.7 \\
\hline November & 32,744 & 64,474 & 11,519 & 17.9 & $\begin{array}{l}31,730 \\
1751\end{array}$ & 36.3 & 9519 & 21,038 & 32.6 & 19,038 & 30,557 & 47.4 & 22,211 & 33,730 & 52.3 \\
\hline December & $\begin{array}{l}35,982 \\
\end{array}$ & $\begin{array}{l}53,493 \\
\end{array}$ & $\begin{array}{ll}11,401 \\
28\end{array}$ & 21.3 & $\begin{array}{l}17,511 \\
73259\end{array}$ & 65.1 & 5253 & $\begin{array}{l}16,654 \\
5,7070\end{array}$ & 31.1 & 10,506 & $\begin{array}{l}21,908 \\
772066\end{array}$ & 41.0 & $\begin{array}{l}12,258 \\
5170\end{array}$ & $\begin{array}{l}23,658 \\
0,0257\end{array}$ & 44.2 \\
\hline Total & 333,262 & 407,120 & 28,551 & 7.0 & 73,858 & 38.7 & 22,157 & 50,708 & 12.5 & 44,314 & 72,866 & 17.9 & 51,701 & 80,251 & 19.7 \\
\hline
\end{tabular}

Table 5. Total and COVID-19 deaths in the Silesian voivodship in 2020.

\begin{tabular}{|c|c|c|c|c|c|c|c|c|c|c|c|c|c|c|c|}
\hline \multirow{3}{*}{ Month } & A1 & A2 & A3 & A4 & A5 & A6 & A7 & A8 & A9 & A10 & A11 & A12 & A13 & A14 & A15 \\
\hline & $\begin{array}{c}\text { An Average } \\
\text { Value in the } \\
\text { Period } \\
2017-2019\end{array}$ & $\begin{array}{l}\text { Deaths } \\
\text { in 2020 } \\
(n)\end{array}$ & $\begin{array}{c}\text { Reported } \\
\text { Deaths } \\
\text { COVID-19 }(n)\end{array}$ & $\begin{array}{l}\text { \% of COVID-19 } \\
\text { Deatths in Total } \\
\text { Deaths (2020) }\end{array}$ & $\begin{array}{c}\text { Excess } \\
\text { Deaths } X\end{array}$ & $\begin{array}{l}\text { Proportion of } \\
\text { COVID-19 } \\
\text { Deaths in } \\
\text { Excess Deaths } \\
(\%)\end{array}$ & $\begin{array}{l}\text { First Scenario } \\
30 \% \text { of Excess } \\
\text { Deaths }(n)\end{array}$ & $\begin{array}{c}\text { First Scenario } \\
\text { Reported }+ \\
\text { Estimated } \\
\text { COVID-19 } \\
\text { Deaths }(n)\end{array}$ & $\begin{array}{l}\text { First Scenario } \\
\text { Estimated } \\
\text { coviD-19 Deaths } \\
\text { in Total Deaths } \\
\text { 30\%+Reported } \\
\text { Deaths }(\%)\end{array}$ & $\begin{array}{c}\text { Second } \\
\text { Scenario } 60 \% \text { of } \\
\text { Excess Deaths } \\
(n)\end{array}$ & $\begin{array}{l}\text { Second } \\
\text { Scenario } \\
\text { Reported }+ \\
\text { Estimated } \\
\text { COVID -19 } \\
\text { Deaths }(n)\end{array}$ & $\begin{array}{l}\text { Second Scenario } \\
\text { Estimated COVID-19 } \\
\text { Deaths in Total } \\
\text { Deaths } 60 \%+ \\
\text { Reported Deaths }(\%)\end{array}$ & $\begin{array}{l}\text { Third Scenario } \\
70 \% \text { of Excess } \\
\text { Deaths }(n)\end{array}$ & $\begin{array}{c}\text { Third Scenario } \\
\text { Reported }+ \\
\text { Estimated } \\
\text { COVID-19 } \\
\text { Deaths }(n)\end{array}$ & $\begin{array}{c}\text { Third Scenario } \\
\text { Estimated COVID-19 } \\
\text { Deaths in Total } \\
\text { Deaths } 70 \%+ \\
\text { Reported Deaths (\%) }\end{array}$ \\
\hline & A1 & A2 & A3 & $\mathrm{A} 3 / \mathrm{A} 2$ & $\mathrm{~A} 2-\mathrm{A} 1$ & $\mathrm{~A} 3 / \mathrm{A} 5$ & $30 \% \times \mathrm{A} 5$ & $\mathrm{~A} 7+\mathrm{A} 3$ & $\mathrm{~A} 8 / \mathrm{A} 2$ & $60 \% \times \mathbf{A} 5$ & $\mathrm{~A} 10+\mathrm{A} 3$ & $\mathrm{~A} 11 / \mathrm{A} 2$ & $70 \% \times \mathbf{A} 5$ & $\mathrm{~A} 13+\mathrm{A} 3$ & A14/A2 \\
\hline March & 4723 & 4735 & 8 & 0.16 & 12 & 66.6 & 4 & 16 & 0.3 & 7 & 19 & 0.4 & 8 & 20 & 0.4 \\
\hline April & 4175 & 4296 & 110 & 2.56 & 121 & 90.9 & 36 & 157 & 3.6 & 72 & 193 & 4.4 & 84 & 231 & 5.3 \\
\hline May & $\begin{array}{l}4079 \\
4079\end{array}$ & 4355 & 90 & 2.06 & 276 & 32.6 & 83 & 359 & 8.2 & 165 & 441 & $\begin{array}{l}1 . t \\
10.1\end{array}$ & 193 & 366 & 8.4 \\
\hline June & 3940 & 4104 & 121 & 2.94 & 164 & 73.7 & 49 & 213 & 5.1 & 98 & 262 & 6.3 & 114 & 285 & 6.9 \\
\hline July & 4085 & 4245 & 61 & 1.43 & 160 & 38.1 & 48 & 208 & 4.8 & 96 & 256 & 6.0 & 112 & 221 & 5.2 \\
\hline October & 4309 & 6283 & 372 & 5.92 & 1974 & 18.8 & 592 & 2566 & 40.8 & 1184 & 3158 & 50.2 & 1381 & 2346 & 37.3 \\
\hline November & 4166 & 7746 & 1303 & 16.83 & 3580 & 36.3 & 1074 & 4654 & 60.0 & 2148 & 5728 & 73.9 & 2506 & 4883 & 63.0 \\
\hline December & 4518 & 6227 & 1175 & 18.86 & 1709 & 68.7 & 513 & 2222 & 35.6 & 1025 & 2734 & 43.9 & 1196 & 2884 & 46.3 \\
\hline Total & 41,911 & 50,804 & 3404 & 7.01 & 8893 & 38.2 & 2668 & 6072 & 11.9 & 5335 & 8740 & 17.2 & 6225 & 12,297 & 24.2 \\
\hline
\end{tabular}




\section{Discussion}

The increased number of total death in 2020 is noticed in different World locations and is an undisputable phenomenon [16]. The only question is, what is the scale of additional death increase, and how many of that excess deaths are attributed to COVID-19 infections. In Poland, in comparison to the average number of deaths from 2017 to 2019, it was 17\% increase, while in the Silesia voivodship it was $16 \%$. Month-to-month (2020 vs. mean 2017-2019) comparison of deaths showed the different scale of excess deaths from 1 to $91 \%$ with an increased proportion in the second half of 2020. Such a situation was characteristic for Poland as well as for the Silesian voivodship.

In Belgium, the total increase in excess deaths attributed to COVID-19 accounted for $96 \%$ [17]. In the USA, the number of excess all-cause deaths was $28 \%$ higher than the officially reported COVID-19 deaths during that period [10], others have suggested a lower number of excessed deaths [12].

Several countries had more than double the historical weekly all-cause mortality during the peak of the pandemic, including Ecuador (497\%), Peru (304\%), Spain (257\%), and the UK (201\%), whereas some countries did not across 200\%, e.g., Chile (170\%), France $(159 \%)$, Italy (185\%), the Netherlands (175\%), South Africa (165\%), and Sweden (150\%). Denmark, New Zealand, and Norway had fewer deaths in 2020 compared to the previous years [4]. The detailed results are included in Table 1 from Kung's study which was the basis of the methodology of our paper.

The conclusion in the article provided by Kung et al. was that the "number of deaths attributed to COVID-19 are underestimated by at least 35\%" [4]. In our study, we suggested that COVID-19 could cause no more than $19.7 \%$ of all deaths in Poland in 2020 . We performed a simulation for Poland, with emphasis on the Silesian voivodship, a densely populated region in Southern Poland. Covid-19 caused an estimated 24\% of all total number of deaths in the Silesian voivodship, which corresponds with results of time-delay estimation that accounted for $20 \%$ performed elsewhere [13]. That could be related to the highest incidence rate of COVID-19 in a chosen region, and at the same time, the region with the highest number of deaths because of COVID-19.

On the other hand, it is worth noting that the COVID epidemic caused, in practice, total inefficiency of the health care system in Poland, with very limited access not only to specialist, planned diagnostic procedures or operations but also to basic family doctors. We expect that consequences of this situation must increase the number of deaths not related directly to the COVID-19 infection.

The limitation of our study is lack of access to the death certificates. These are simulations base on officially published data, but at this moment, there are no better source of the data in Poland. Unfortunately, currently available data do not allow us yet to perform plausible separate simulations for Poland according to gender or different age groups. Our research based on data from hospital deaths in Silesia revealed that the risk of death in COVID-19 hospitalized patients is greater in men than in women (OR (Odds ratio), 1.35; $95 \%$ CI, 1.07-1.70), and increases with age and with the number of coexisting diseases (mostly with chronic cardiovascular, respiratory, and metabolic diseases) [18].

Another limitation of our simulation is that the number of excess deaths did not include COVID-19 testing before the beginning of the epidemy. However, we included in our calculation the only period in which the Polish government officially started testing against COVID-19. Another limitation of our study is that some people may have died of COVID-19 but were not diagnosed because of situation the pandemic presented [13]. In some populations, it was even 50\% [15]. As we showed in our previous research, the real number of COVID-19 infections in the Silesia region (11.5\%) may be four times higher as an official prevalence (2.8\%) [9]. The other issue is reserved for problems with giving a proper reason for death because some direct deaths attributed to COVID-19 may be assigned to other causes of death. There might be plenty of reasons for such situation like physician mistake (due to overwork), inability to test every patient for COVID-19, and finally, time lag between infection, recovery, and cause of death. 
In our simulation, we were not able to include indirect consequences of the COVID-19 pandemic. People resigned from medical health care services due to the lockdown, and their resignation was related to panic fear of pandemic and irrational behaviors, which delayed diagnosis and treatment $[19,20]$.

Without any doubt, the epidemy of SARS-Cov2 caused an excess number of deaths in Poland from the beginning of 2020. However, despite the role that COVID-19 played in those excessed deaths, as well, it should not be refused that the number of other causes of death was less important. It seems that people were more likely to die because of cardiovascular diseases or respiratory diseases due to resignation from medical services or difficulty access to specialists or general practitioners.

\section{Conclusions}

COVID-19 had an impact on the excess number of deaths in Poland in 2020. However, the simulation shows that participation of COVID-19 in total deaths should not exceed 20\% for Poland and $24 \%$ for the Silesian voivodship in 2020.

Author Contributions: Conceptualization, M.K.; methodology, K.B., M.K., and G.B.; data curation, G.B., M.K., and A.K.-P.; formal analysis, K.B.; investigation, K.B., G.B., M.K., and A.K.-P.; writingoriginal draft preparation, K.B., G.B., M.K., and A.K.-P.; writing—review and editing, K.B., G.B., M.K., and A.K.-P.; visualization, K.B. and M.K.; supervision, J.E.Z.; project administration, J.E.Z.; funding acquisition, J.E.Z. All authors have read and agreed to the published version of the manuscript.

Funding: The results of the study is a consequence of a project titled: Prevalence and Risk Factors of COVID-19 in the Upper Silesian Agglomeration (EpiSARS2) supported by the Medical Research Agency in Poland (2020/ABM/COVID19/0044).

Institutional Review Board Statement: Not aplicable.

Informed Consent Statement: Not aplicable.

Data Availability Statement: The data is available free of charge from national reports (Polish Statistical Office).

Acknowledgments: We would like to express our gratitude to Felix Danso (Cleveland State University) for the improvements to the English language of this manuscript.

Conflicts of Interest: The authors declare no conflict of interest.

\section{References}

1. Ministry of Health (Poland). Available online: https://www.gov.pl/web/zdrowie/pierwszy-przypadek-koronawirusa-w-polsce (accessed on 1 February 2021).

2. Number of Deaths Registered in the Registry of Civil Status. Available online: https://dane.gov.pl/pl/dataset/1953,liczbazgonow-zarejestrowanych-w-rejestrze-stanu-cywilnego (accessed on 1 February 2021).

3. Statistics Poland-Local Data Bank. Available online: https://bdl.stat.gov.pl/BDL/start (accessed on 29 January 2021).

4. Kung, S.; Doppen, M.; Black, M.; Braithwaite, I.; Kearns, C.; Weatherall, M.; Beasley, R.; Kearns, N. Underestimation of COVID-19 mortality during the pandemic. ERJ Open Res. 2021, 1-7. [CrossRef]

5. Woolf, S.H.; Chapman, D.A.; Sabo, R.T.; Weinberger, D.M.; Hill, L.; Taylor, D.D.H. Excess deaths from COVID-19 and other causes, March-July 2020. JAMA 2020, 324, 1562-1564. [CrossRef] [PubMed]

6. Stokes, C.A.; Lundberg, D.J.; Hempstead, K.; Elo, I.T.; Preston, S.H. Assessing the impact of the COVID-19 pandemic on US mortality: A county-level analysis. medRxiv 2020. [CrossRef]

7. Shiels, M.S.; Almeida, J.S.; Garcia-Closas, M.; Albert, P.S.; Freedman, N.D.; de Gonzalez, A.B. Impact of population growth and aging on estimates of excess U.S. deaths during the COVID-19 pandemic, March to August 2020. Ann. Intern. Med. 2020. [CrossRef]

8. Krelle, H.; Barclay, C.; Tallack, C. Understanding Excess Mortality What Is the Fairest Way to Compare COVID-19 Deaths Internationally; The Health Foundation: London, UK, 2020; Available online: https://www.health.org.uk/news-and-comment/ charts-and-infographics/understanding-excess-mortality-the-fairest-way-to-make-international-comparisons (accessed on 11 February 2021).

9. Zejda, J.E.; Brożek, G.; Kowalska, M. Seroprevalence of Anti-SARS-CoV-2 antibodies in a random sample of inhabitants of the katowice region, Poland. Int. J. Environ. Res. Public Health 2021, 18, 3188. [CrossRef] [PubMed] 
10. Weinberger, M.D.; Chen, J.; Cohen, T. Estimation of excess deaths associated with the COVID-19 Pandemic in the United States, March to May 2020. JAMA Intern. Med. 2020, 180, 1336-1344. [CrossRef] [PubMed]

11. Ministry of Health (Poland): Informacja o Zgonach w Polsce 2020 Roku, Luty 2020. Available online: https:/ /www.gov.pl/web/ zdrowie/raport-o-zgonach-w-polsce-w-2020-r (accessed on 11 February 2021).

12. Stang, A.; Standl, F.; Kowall, B.; Brune, B.; Böttchere, J.; Brinkmannf, M.; Dittmerg, U.; Jöckela, K.-H. Excess mortality due to COVID-19 in Germany. J. Infect. 2020, 81, 797-801. [CrossRef] [PubMed]

13. Baud, D.; Qi, X.; Nielsen-Saines, K.; Musso, D.; Pomar, L.; Favre, G. Real estimates of mortality following COVID-19 infection. Lancet Infect. Dis. 2020, 20, 773. [CrossRef]

14. Vadoros, S. Excess mortality during the COVID-19 pandemic: Early evidence from England and Wales. Soc. Sci. Med. 2020, 258, 113101. [CrossRef] [PubMed]

15. Vieira, A.; Peixoto, V.R.; Aguiar, P.; Abrantes, A. Rapid estimation of excess mortality during the COVID-19 pandemic in Portugal-Beyond reported deaths. J. Epidemiol. Glob. Health 2020, 10, 209-213. [CrossRef] [PubMed]

16. Manucci, E.; Nreu, B.; Manomi, M. Factors associated with increased all-cause mortality during the COVID-19 pandemic in Italy. Int. J. Infect. Dis. 2020, 98, 121-124. [CrossRef] [PubMed]

17. Sierra, N.B.; Bossuyt, N.; Braeye, T.; Leroy, M.; Moyersoen, I.; Peeters, I.; Scohy, A.; Van Der Heyden, J.; Van Oyen, H.; Renard, F. All-cause mortality supports the COVID-19 mortality in Belgium and comparison with major fatal events of the last century. Arch. Public Health 2020, 78. [CrossRef]

18. Kowalska, M.; Barański, K.; Brożek, G.; Kaleta-Pilarska, A.; Zejda, J.E. COVID-19 related risk of in-hospital death in Silesia, Poland. Pol. Arch. Med. Intern. Med. 2021, 1-21. [CrossRef]

19. Medline, A.; Hayes, L.; Valdez, K.; Hayashi, A.; Vahedi, F.; Capell, W.; Sonnenberg, J.; Glick, Z.; Klausner, J.D. Evaluating the impact of stay-at-home orders on the time to reach the peak burden of COVID-19 cases and deaths: Does timing matter? BMC Public Health 2020, 20, 1-7. [CrossRef] [PubMed]

20. Reinstadler, S.J.; Reindl, M.; Lechner, I.; Holzknecht, M.; Tiller, C.; Roithinger, F.X.; Frick, M.; Hoppe, U.C.; Jirak, P.; Berger, R.; et al. Effect of the COVID-19 pandemic on treatment delays in patients with ST-segment elevation myocardial infarction. J. Clin. Med. 2020, 9, 2183. [CrossRef] [PubMed] 